\title{
Nataša Golob
}

\section{O spominu in spominski podobi v srednjem veku}

\author{
Ključne besede: naslikane ključne besede, kazalke, traktati o spominu, medicinska \\ dela o možganih in spominu
}

DOI: $10.4312 /$ ars.12.2.252-270

\section{Zapisi o zapomnjenju podobe}

Kadar govorimo o ciljih in namenih, ki so jih srednjeveški umetniki vnesli v svoja dela, se je treba odmakniti od umetnostnozgodovinske slogovne analize in se osredotočiti na izvirno zlitje razumevanja in doživljanja stvaritve. Ne naša interpretacija, prvo besedo imata srednjeveški ustvarjalec in njegovo občinstvo, gledalec, poslušalec. Razen za izjeme, za dela, ki so bila namenjena individualnemu gledalcu, torej javnosti v edninski obliki, ne moremo reči, da bi likovne ali literarne stvaritve obstajale v »zaprtem svetu« (Klarer, 1999, op. 6). Gregor I. je v pismu prijatelju Serenu, škofu v Marseillu, jasno povedal, da se lahko nepismena oseba uči krščanskih resnic ob upodobitvah, ker se jih $\mathrm{v}$ zapisani besedi ne more. Tako stoji $\mathrm{v}$ pismu iz leta 599 - in to opozorilo, ki izpostavlja moč likovnega dela kot izhodišča za razmišljanje o sporočilih krščanske misli, je ostalo v občem spominu, le da v okrnjeni in s tem potvorjeni, prirejeni obliki. Gregor Veliki je zapisal približno takole: »Eno je občudovati (oboževati, častiti) podobo, nekaj drugega je naučiti se skozi upodobljeno pripoved, kaj je vredno (potrebno) častiti. Ker tisto, kar besedilo daje osebam, ki ga berejo, lahko upodobitev ponudi (omogoči) neizobraženemu; v upodobitvah se (branja) neuki ${ }^{1}$ seznanijo s svojimi dolžnostmi in to berejo (prepoznajo, razumejo), ne da bi poznali črke. Zato imajo upodobitve posebej za preproste ljudi vlogo (veljavo, mesto) berila. $\aleph^{2}$

1 Gregor Veliki uporablja samostalnik illiteratus; ta je v njegovem času pomenil osebo, ki ni znala pisati (in včasih tudi brati) v latinščini. Pozneje so avtorji vpeljali besedno zvezo semi-litteratus za osebe, ki so bile vešče branja in razumevanja prebranega, niso pa obvladale veščine pisanja. Ne illiteratus ne semi-litteratus pa nista enakoznačnici za neizobraženo, neuko ali celo neumno osebo. - Odveč je opozorilo, da je treba srednjeveške oznake uporabljati samo v okvirih njihovega časa.

2 Prosti prevod po: Registrum epistolarum, CCSL, 140A, 874.22-874.26; v drugih kompendijih je pismo navedeno tudi z oznakami Liber XI, epistola 13. Gregorjeva pisma so dostopna v številnih edicijah in spletnih mestih. - Članek Gabrielle K. Sprigrath o Gregorjevih pismih škofu Serenu obravnava tudi druga vprašanja predkarolinške in karolinške umetnosti skozi analizo umetnostnozgodovinskih poenostavitev. V kontekstu dilem glede ikonoklazma in ikonodulije med latinskim Zahodom in grškim Vzhodom gl.: Freeman 1993/1994, str. 166; in posebej glede pisma Gregorja Velikega: Duggan, 2005, 109-119. 
V zgodnjem srednjem veku, ki je bil glede krščanske doktrine do umetnosti formativno obdobje, so podobna stališča zapisali številni avtorji, s tem pa so utrli prosto pot odločitvi, naj bodo likovne stvaritve del življenja, vključene v utečeno bogoslužje: pomembne so za utrjevanje krščanskega in moralnega ravnanja. Vsaj v času Karla Velikega so se pojasnila stališča, kaj je ikonodulija (kot nasprotje ikonoklazmu) in v čem je pomen likovne umetnosti, ki podpira liturgično in šolsko reformo v karolinškem kraljestvu oz. cesarstvu; pri oblikovanju dekretov je imel veliko vlogo učeni Alkuin, gibalo kulturnega vzpona.

Tisti, ki si ni natančno zapomnil celotnega odlomka iz Gregorjevega pisma, je njegove misli o pomenu upodobitev skrčil na raven, češ da so ta dela zgolj oblika poučevanja neukih. Navajanje samo nekaj Gregorjevih besed je razvrednotilo bistvo (Appleby, 2002, 87): likovnim delom je odvzelo vse druge funkcije, izbrisalo je možnost, da gledalec ob njih dobi navdih, da pogled na kompozicijo sproži proces spominjanja, da se ob motrenju podobe povežejo izkušnje in predstave, da se ob nekem prizoru razmišljanje zlije v njihovo dograjevanje, v nove idejne vrednote, da se gledalec ob upodobljenih motivih vpraša o poteh moralnega napredovanja, kar je bila ena od maksim Cerkve v karolinškem času.

Iz besed Gregorja Velikega je že razvidno, da mu je bil jasen pomen umetnosti in znanja, da je ločil ravni dojemanja in sprejemanja, kar je veljalo tudi za druge vodilne osebnosti, sicer ne bi o tem razpravljal s Serenom. Cerkev je - kakor kaže njegova papeška drža - upoštevala proces individualnega in kolektivnega razvoja na temelju izkušenj, spomina posameznika in skupnosti, da so likovna in literarna dela - tudi če tega niso neposredno izrazili - dve obliki enega večumetnostnega polja. M. Carruthers je pokazala, da se koncepti upodobitev (in s tem posredno povezani spomini na tekstualna sporočila) zlivajo v celovitost duhovnega in da je zato »branje podob « sicer oseben proces, a kot tak kljub temu lasten tudi vsej (latinski) ekumeni. Srednjeveška besedila o duši govorijo o pretvorbi podob-podobja-upodobitev, ki se odvija v človekovi notranjosti, tako da se ne glede na religiozni cilj v teh besedilih zrcalijo predvsem analize človekovih miselnih in čustvenih poti. ${ }^{3} \mathrm{Ne}$ dotikajo se samo vizualnega zaznavanja, ampak tudi sanj, videnj, spominov in stikov vseh vrst, tako da je iz tega mogoče izluščiti delitev na zunanjo in notranjo resničnost. ${ }^{4}$ Zunanje zaznave posredujejo vtise notranjim čutom, ki so povezani $\mathrm{z}$ možgani in so obče znani vid, sluh, voh, okus in otip. Razmerje med zunanjim in notranjim zaznavanjem je latinskemu delu Evrope približal prevod Avicennovega Kanona

3 Mary Carruthers se je vprašanju procesov, ki spadajo v domeno anatomije, posvetila v poglavju The description of the neuropsychology of memory knjige The Book of Memory, 1990, 46-79. 
medicine, ${ }^{5}$ ki je z izkušnjami arabske medicine nadomestil starejše medle in široke opise zaznavanja (Slika 1$){ }^{6}$

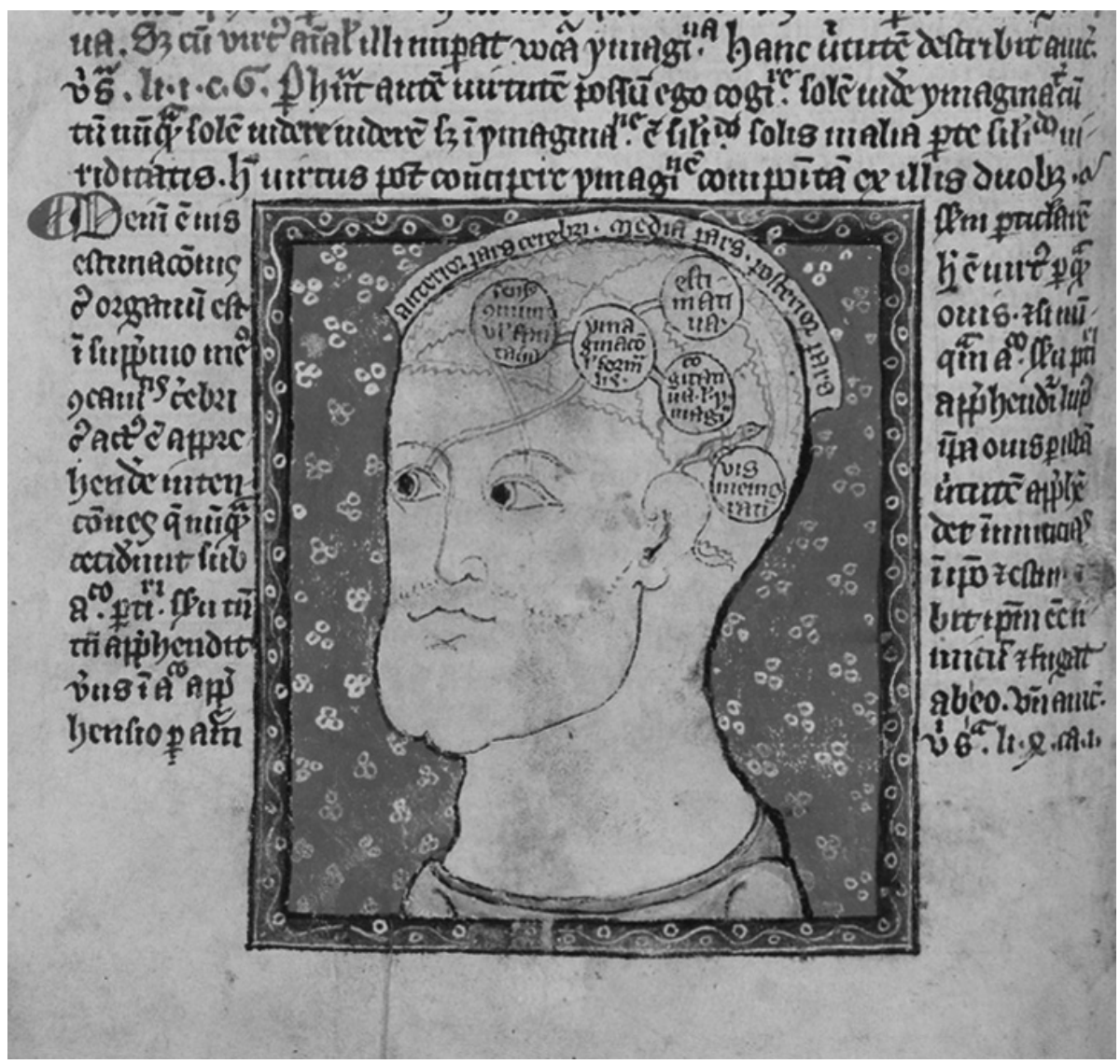

Slika 1: Qualiter caput hominis situatur (fol. 491v), Trilingual compendium of texts, po 1307, angleško delo. Cambridge, University Library, Ms Gg 1.1, https://cudl.lib.cam.ac.uk/view/MS-GG-00001-00001/988.

Ne sme nas presenetiti, da je Avicennov tekst postavil vid na prvo mesto. Poudarjale so ga vse srednjeveške enciklopedije, kar je v dobršni meri dediščina Platonovega Timaja (45b-47), edinega v srednjem veku v celoti dostopnega Platonovega dela,

5 Še vedno je ohranjenih skoraj 300 srednjeveških prepisov Avicennovih del, bodisi v celoti ali v odlomkih.

6 Rokopis iz časa ok. 1327-1330 (vsekakor po 1307) z Avicennovim traktatom na fol. 490v vsebuje risbo glave, kjer so posamezne intelektualne dejavnosti označene kot razdelki, cellae, povezujejo pa jih kanali, nervi, ki vsi potekajo iz očesa. Cellae so poimenovane sensus communis (zdrava pamet), ymaginatio et vis formalis, cogitatiua et imaginatiua, estimatiua ter v zatilju vis memoratiua. Cambridge, University Library, Gg 1.1 (sl. 1); gl. Carruthers, M., 2012, 373. 
ki je prek žarenja zunanjega in notranjega vida izpostavilo pomen uma, dojemanja. Obe obliki vida sta komplementarni, vendar samo notranji vid ustvarja mentalne podobe, med katere spada spomin oz. podobe iz spomina. ${ }^{7}$ Kakor pove marsikatera srednjeveška enciklopedija, ${ }^{8}$ izvirajo te imagines iz notranjega očesa, sam oculus imaginationis pa je usklajen s standardnimi anatomskimi zamislimi, ki jih razlagajo enciklopedije. Vnovič je izhodišče antično, ker so se oprle na Galenovo teorijo, da možgane tvorijo trije segmenti: za čelno partijo je locus imaginationis, na sredini, pod temenom, je locus rationalis (logica), zatilje pa varuje območje spomina: memoratiua je domena uma oz. duhà ter varuje podobe predmetov, da jih ne bi pozabili. ${ }^{9}$

Nekaj stoletij pozneje se je v enciklopediji Izidorja iz Seville odlomku o spominu pridružilo opozorilo na moralno odgovornost: spomin je imanentno vezan na minulost in je zato orodje zgodovinarjev. Prav v tem segmentu mu je Izidor namenil pripombo. V I. knjigi $(41,1-2)$ namreč zahteva, naj zgodovinarji opravijo svoje delo kakor je treba, naj ne zapisujejo pripovedi, ki jih ni mogoče preveriti, in naj se vrnejo k izhodišču: historia govori o resničnih dogodkih, ki so se zares zgodili, beseda pa ima korenine v grščini, kjer historein pomeni videti (!) in razumeti (!). Zgodovinar mora sporočati o dogodkih, ki jih je zares videl, ${ }^{10}$ iz tega pa lahko razberemo opozorilno misel, da se dogodki v spominu sčasoma predrugačijo.

Pri Izidorju Seviljskem pa gre še za nekaj več: v letih njegovega intelektualnega razvoja status zapisane besede ni bil več identičen $\mathrm{z}$ mestom, vlogo in pomenom definiranega besedila v pozni antiki, zato se je v I. knjigi nekajkrat vrnil k vprašanjem, ki sta jih obravnavala Sergij (glede Donatove slovnice) in Avrelij Avguštin (v knjigi O Sveti trojici). Tako kot onadva je imel tudi Izidor zapisano besedilo za spomenik, torej za nekaj, kar ima zgodovinsko avtentičnost. Zapisovanje (litterarum) se je razvijalo zato, ker je bilo treba ohraniti spomin, saj si je nemogoče vse zapomniti samo s poslušanjem (... usus litterarum repertus est propter memoriam ... nec disci audiendo

7 Shema možganskih funkcij, povezav med posameznimi centri in odvisnosti od čutov je narisana $\mathrm{v}$ rokopisu iz leta 1347. Mario Klarer navaja, da gre za rokopis: Avicennus: De generatione embryonis, München, Bayerische Staatsbibliothek, clm 527, fol. 64r, vendar gre očitno za napako pri podpisu k sliki.

8 Klarer, 1999, 36, sicer ne omenja neposredno enciklopedije De proprietatibus rerum Jerneja Angleškega (Bartholomaeus Anglicus, pred 1203-1272), vendar je bila med srednjeveškimi enciklopedijami posebej pomembna. Kot profesor v Parizu je to knjigo napisal v latinščini, v 14 . stoletju pa so jo prevedli v francoščino in angleščino.

9 Povzeto po: Liber de proprietatibus rerum Bartholomei Anglici Ordinus minorum, Argentoratum 1505 (München, Bayerische Staatsbibliothek, sign. BSB 00018287-9), Liber III., Cap. VI.: De potentiis anime.

10 Coleman, J. (1995, 229-324), poglavje ima naslov Beginnings of the scholastic understanding of memory d Medieval Memories; avtorica opozarja, da je Izidorjev zagovor videnega (!) dogodka zagovor znanstvenega dela. $\mathrm{V}$ tem poglavju se razgrinja kontekst poznoantičnega in predkarolinškega spomina, po katerem so v zgodnjih stoletjih srednjega veka dogodke sprejemali kot uresničenje Božjega načrta. 
poterant omnia, nec memoria contineri, XX, I, 3). Izidor ne govori o prenosu sporočila na tretjo osebo in pomnjenju, njegove besede se nanašajo na prvoosebno stališče: gre mu tako za vizualni kot verbalni spomin, ki temelji na poznavanju/spominjanju pomena črk, oblikovanja besed ter celovitosti stavkov in misli. Izidorjeva navezanost na videno podobo črk oz. misli ali definicij pa se ni končala s tekstom. Knjige etimologij so bralcu stopile naproti tako, da so vključile risbe, sheme in geometrijsko ponazorjena razmerja; za vsa naslednja stoletja so postale pomembne likovno izražene povezave (kar je oblika miselnih vzorcev). V poglavju o zapisovanju so npr. risbe ločil in naglasov, še kako pomembnih za pravilno branje in razumevanje ( $D e$ posituris in De notis sententiarum). ${ }^{11}$ Zares, marsikateri bralec - posebej če ni bil vsestransko izobražen - iz stvarnega opisa diakritičnega ali korekturnega znaka ne bi mogel ločiti nekaterih med njimi (recimo tistih, ki jim Izidor reče paragraphus ali positura) ter na drugi strani ugotoviti razlik glede citatnega znaka, imenovanega diplè.

Izidor Seviljski je pri svojih odločitvah, da v besedila vključi pojasnjevalne risbe, nedvomno segel $\mathrm{k}$ starejšim tradicijam, $\mathrm{k}$ znanstvenim edicijam helenistično-rimske knjižne kulture. K temu vidiku vizualne razlage se bom vrnila, tu pa naj vsaj omenim, da je bila ves srednji vek prisotna Aristotelova misel o distinktivnih naravah spomina oz. pomnjenja, glede na čas, prostor, osebo in vsebino. Zapisana je v različnih spisih, med drugim v temeljnem delu o slojevitosti mentalnih kapacitet in dojemanja, to je $O$ duši, De anima. ${ }^{12}$ Posebej pa je tej temi namenil razpravo O spominu in spominjanju (De memoria et recollectio), jo analiziral $\mathrm{z}$ vseh plati ter jo vzidal $\mathrm{v}$ kontinuiteto krščanskega dojemanja stvarstva in navsezadnje tudi umetnosti. V besedah, da »... spomin pripada tistemu delu duše, ki ji pripada imaginacija «, se je njegov svet staknil s stališčem Gregorja Velikega. Trajnostni značaj spomina - vsaj za umetnost - pa je mogoče sprevideti v nadaljevanju, ko pravi, da »... so vsi (stvarni) predmeti, ki si jih je mogoče predstavljati, v temelju predmeti spomina, tisti, ki pa so v bistvu predmeti imaginacije, so le naključno objekti spomina ${ }^{13}{ }^{13}$ Aristotel je glede spomina prav tako določil mesto zunanjega in notranjega vida oz. vida objektivne stvarnosti in vida $\mathrm{v}$ duhu ustvarjene stvarnosti. To je sicer poenostavitev njegovih besed, a hkrati je v prav takem smislu precej pogost motiv v šolah: $\mathrm{v}$ srednjeveški trivialki so $\mathrm{v}$ okviru

11 Malcolm Beckwith Parkes, Changing Attitudes to the Written Word: Components in a 'Grammar of Legibility', Pause and Effect. An Introduction to the History of Punctuation in the West, Cambridge 1992, 20-29, str. 22; M. B. Parkes je te besede ponazoril s stranjo iz karolinške kopije Izidorjeve enciklopedije; to je sedaj rokopis: Wolfenbüttel, Herzog August Bibliothek, Weissenburg Ms 64, fol. $13 \mathrm{v}$, pl. $7, \mathrm{p} .172$.

12 Aristotelovemu odnosu do spomina se je v tej številki revije Ars \& Humanitas posvetilo nekaj kompetentnih raziskovalcev njegove misli in vplivov.

13 Aristotle (1957, I, 288-313): celotno besedilo O spominu in spominjanju (288-313) se pozneje še vrne $\mathrm{k}$ tematskemu razlikovanju obeh kvalitet. Vplivno je bilo njegovo opažanje, da je spominjanje lahko v celoti natančno, le pri opredeljevanju časa so zdrsi; gl. str. 293 in 309. 
predmeta, ki je posredoval temelje logike, zelo visoko postavili dojemanje vsebin (in prav tako v nadaljevanju Aristotelovih spisov vaje v argumentaciji). Če je v 11. in 12. stoletju humanistika (kot celovit sklop) izrazito upoštevala gramatiko in retoriko, je $\mathrm{v}$ 13. stoletju prevladala Aristotelova logika kot eden temeljnih predmetov na univerzah, med katerimi sta takrat najbolj slovela Pariz in Cambridge. Vrnitev logike na vodilno mesto je treba videti skozi prizmo vrnitve $\mathrm{k}$ antični dediščini, predvsem h klasični literarni dediščini (Cobban, 1999, 150-151).

\section{Sobivanje zapisa in podobe}

Težje razložljive in obsežne miselne strukture so bile nedvomno zelo zgodaj deležne vizualne podpore, ${ }^{14}$ ker že vsaj fragmentarno ohranjena dela (znanstvena in literarna) vsebujejo likovne prvine, in sicer znotraj besedila, ki ga kot likovno polje (a campo aperto) prekinjajo ali pa $\mathrm{z}$ margin dopolnjujejo. Knjiga je v vseh svojih oblikah - od glinastih ploščic in lesenih knjig do zvitkov - vselej dovoljevala sobivanje besede in slike, naj je bil razlog povsem estetske ali funkcionalne narave. Pojasnjevalna risba je tako rekoč alter ego napisanega in je (sekundarni) ${ }^{15}$ del vsebine, saj je znanje kvaliteta, ki se nenehno spreminja, je del dinamičnih struktur, ki določajo človekovo življenje in delovanje. Vstopa v proces dojemanja, ker avtor tudi prek nje komunicira z osebo/osebami, ki bodo ob knjigi. Gre za »um druge osebe«, o tem pa ni mogoče govoriti posplošeno, vsak um je poseben, zato je dojemanje in komuniciranje povsem individualna in procesno-razvojna situacija. ${ }^{16}$

14 Zaenkrat ne vem, kateri je najstarejši ohranjeni srednjeveški rokopis, ki diagramsko predstavlja strukture spomina in mišljenja v Aristotelovih delih. Je pa posebej od 12. stoletja dalje nastalo veliko risarsko podprtih rokopisov, v katerih so ponazorjena razmerja med Aristotelovimi kategorijami. Tako je znan kodeks s spisoma Categoriae ali De interpretationeo s čistimi, geometrijsko zasnovanimi kompozicijami in zato jasnimi razmerji, ki so jih kopirali v več samostanskih šolah; St. Gallen, Stiftsbibliothek, Hs. Nr. 818; gl. Das Kloster St. Gallen, str. 54-55. - Odmev teh šolskih rokopisov je bil dolgotrajen; za aristokratske bralce so bili spremenjeni v lepe diagramske strukture, ki so mnemotehnično podprle Aristotelove spise, npr. južnofrancoski rokopis z Analytica priora, Analytica posteriora, Topica, De sophisticis elementis; zdaj: Città del Vaticano, Biblioteca apostolica Vaticana, Borg. 130. Gl. Vedere i classici, str. 254-256. Kot ilustracija občega odnosa do Aristotela kot »viteza resnice« je zanimiv rokopis: Thomas Le Myésier: Breviculum ex artibus Raimundi Lulli electum, zdaj: Karlsruhe, Badische Landesbibliothek, St. Peter perg. 92. Rokopis je dostopen na: https://digital. blb-karlsruhe.de/blbhs/content/pageview/105549. Gl. tudi: http://richardzach.org/2017/06/22/ illuminated-manuscript-of-aristotle-averroes-and-ramon-llull-charging-the-tower-of-falsehood/. Proti trdnjavi lažnivosti kot prvi med vitezi jezdi Aristotel, njegov konj je označen kot rationatio, sulica je orožje, polno silogizmov itd.; vsak likovni detajl ima zapisano pomensko oznako.

15 Sekundarni, drugotni del vsebine je preprosto zato, ker nimamo dokazil, da bi diagramske risbe itd. za svoje diseminirano delo predvidel že avtor.

16 Peter Carruthers prav tej dimenziji razpona med razmišljanjem avtorja na eni strani in bralca ter njegovo sposobnostjo, dojemljivostjo, predznanjem ali iskanjem na drugi namenja obsežno poglavje, ki se izteče v pričakovanju avtorja, da je njegovo sporočilo razumljeno brez »nadinterpretacije« (interpretionalism, 248), pa tudi brez zdrsov; gl. poglavje The problem of other mind. Carruthers, P., 2004, 6-23. 
Srednjeveške univerze so bile v prvi vrsti institucije za posredovanje znanja in le $\mathrm{v}$ manjši meri raziskovalno usmerjene skupnosti. Nedvomno so bili zbrani profesorji sposobni odpirati nove poglede, le zadrgnjenost določil jim je postavila meje. ${ }^{17}$ Nekaterim je bilo dano, da so kako zamisel uresničili potem, ko so se iz univerzitetnega umaknili v samostansko ali posvetno okolje. Iz izkušenj so vedeli, da je kompleksno znanje težko posredovati v "gladkem«, vizualno nestrukturiranem berilu: k iskanju vsebinskih poudarkov in ključnih besed so sicer pripomogli rubricirani podnaslovi ipd., ki pa niso dodali ničesar k pojasnjevanju medsebojnih razmerij. Risba oz., širše rečeno, podoba lahko učinkuje kot nadomestilo za celovitost razlage; ${ }^{18}$ tako so srednjeveški rokopisi ob diagramih (le kako bi pojasnili pravne koncepte sorodstvenih razmerij, če ne $\mathrm{z}$ drevesom rodovnih povezav?), geometrijskih kompozicijah in podobnih vizualnih shemah po letu $1200 \mathrm{z}$ veseljem pretvarjali kristalinično nazornost geometriziranih struktur likovne kompozicije. Drevesa abecede, sedmih svobodnih veščin, drevesa dobrega in zlega, človek kot mikrokozmos in njegovo zrcaljenje v makrokozmosu itd. so vstopila v učeni svet, kjer je bila duhovitost vizualnega pomagala sprejemljiva, pravzaprav dobrodošla. Sheme so se modificirale vzporedno z govorjeno in zapisano besedo, ker je bilo 13. stoletje čas, ko se je pridiga kot poseben, angažiran tok širjenja sporočil neverjetno uveljavila. Takrat so npr. razvili traktate o veščini pridiganja (artes praedicandi), kjer je celotno človeško telo kraj (locus) za memoriranje vsebin. To so bila resna znanstvena dela, v katerih se je - po naših pojmovanjih - znanje psihologije, didaktike in pedagogike stekalo proti enemu smotru, v razlago nabožnih in družbeno aktualnih tem.

Med temi traktati velja za eno najbolj izdelanih razprav Summa de arte praedicandi Thomasa de Chobhama, ki ga posebej omenjam zato, ker je le nekaj desetletij starejši od pozneje obravnavanega Monalda Koprskega. ${ }^{19}$ Traktat je do popolnosti razvil sistem logičnega povezovanja in prehajanja od enega (pridižnega) motiva do drugega ter se pri vizualizaciji teh razmerij oprl na dobro uveljavljene vzorce. Traktat je uporabil podobo človekovega telesa kot prostora za hranjenje različnih informacij: caput je lahko oznaka za naslov, je pa seveda (človeška) glava v vizualni shemi vsebinske celote, membra, ki jim pripada členitev glavne teme, se ujemajo s človekovimi udi itd. ${ }^{20}$ To so

17 Cobban $(1999,172)$ položaj srednjeveškega profesorskega kolegija primerja z razmerami, v kakršnih so v okvirih marksistično-leninističnih doktrin delovali kolegi v Sovjetski zvezi: oboji so imeli samo špranje svobode, ki so jih morali poiskati.

18 Plinijeva anekdota o odsotni osebi je primerjava, ki je povsem na mestu: risba, ki je ohranila (vizualni) spomin na osebo, ki je odšla, je lahko paradigma za »ujetje« misli, za »materializacijo» spomina na nekoga ali nekaj, od česar smo ločeni zaradi časovnih in prostorskih dimenzij. D. Tarn Steiner $(2001,5)$ meni, da je učinek takih podob odvisen od specifičnega razmerja med osebo in likovnim izrazilom; nikakor ni nujno, da je med enim in drugim vidna mimetična skladnost, pomembno je zaznavanje nadomeščanja, enakovrednosti ali čustvene povezanosti.

19 Thomas de Chobham (ok. 1160-1233/1236); gl. kritično izdajo: Morenzoni, 296.

20 ... videlicet quod oratio sit connexa et coniuncta in membris suis quod ipsa membra videantur sibi 
pravzaprav miselni vzorci, ki jih je treba razumeti v kontekstu javne pridige, občinstva s cest in trgov, ki je potrebovalo nazorne primerjave. Vprašanje, zakaj je bila odločitev za ta izbor tako dobro sprejeta, nima enoznačnega odgovora, čeprav je razumljivo, da je bila podoba telesa množicam poslušalcev jasna in sprejemljiva opora za razlage. $\mathrm{Ni}$ pa odveč opozoriti, da je $\mathrm{v}$ razgledanih krogih moral ob tem zazveneti spomin na dvoje antičnih detajlov: dekliško ali žensko telo je tako rekoč ostalo sinonim za poosebitve (In kaj so teme pridig? Dobrota, odpuščanje, skromnost ipd.); to pa je spet povezano $\mathrm{z}$ vsebino III. knjige $\mathrm{v}$ Rhetorica ad Herrenium, kjer najdemo tudi namig, da se človeku bolj vtisne $\mathrm{v}$ spomin nekaj prijetnega, posebnega in nevsakdanjega. Vizualizacija vsebinskih sklopov je privzela še druge oblike, npr. podobo arhitekture, gradu ali samo sobe (Rischpler, 2004, 85) ali odprte človeške dlani, živali, ${ }^{21}$ cvetlic itd.

\section{Spominska opozorila v marginalnih upodobitvah}

Ponazarjanje vsebinskih sklopov samo $\mathrm{z}$ diagramskimi risbami ni prišlo v poštev v leksikalnih delih, ki so bila tudi v srednjem veku pogosta pomagala pri znanstvenem in praktičnem delovanju. Delo z njimi je bilo prenekaterikrat zapleteno, vendar ne zaradi uveljavljenega abecednega reda, pač pa zato, ker je bil lahko en pojem uvrščen $\mathrm{v}$ korpus pod sopomenkami ali pa je dobil prostor znotraj obsežnejšega gesla in ga bralec ni zlahka odkril. Dostop do zaželene vsebine je torej zahteval drugačno pot. Zato je vredno opozoriti na rokopis z razlagami pravnih izrazov in razmerij med njimi, kjer je bralec do iskane vsebine prišel s pomočjo obstranskih risb, ne pa diagramov ali miselnih vzorcev. Izstopajoče zgodnji primer znanstvenega kompendija, ki k vsebinam usmerja s pomočjo likovnih marginalij, je rokopis Ms $33 \mathrm{iz}$ Narodne in univerzitetne knjižnice v Ljubljani iz ok. leta 1300. ${ }^{22}$ Pod naslovom Summa de iure canonico je znan kot popoln pravni priročnik, ki ga je ok. leta 1272 napisal Monaldo Koprski (ok. 12101278), zato je to delo pogosto imenovano po avtorju, Summa Monaldina. ${ }^{23}$

naturaliter coherere. Et ponit talem similitudinem: si videt aliquis caput alicuius hominis ingredientis, naturaliter intelligere debet quod sequuntur pectus et manus et pedes et cetera membra. A simili ita debet ordinari predicatio, quod audito capite, id est themate predicationis, statim ex ipso capite intelligat auditor que membra predicator et adiungat, et de quibus membris debeat servare sermonem et expectare. Citirano po: Morenzoni $(1989,296)$.

21 Svetovno znana je risba četveronožca (z ovratnico! - kot da je ukročen ris), ki so ga v Sankt Gallnu narisali v okviru poglavja o razdelitvi matematičnih ved: vsaka noga je za eno, za aritmetiko, geometrijo, glasbo in astronomijo. Das Kloster St. Gallen und seine Schulen, 2009, slika na ovitku ter 22 .

22 Prvi celovit opis: Kos-Stelè, 1931, str. 61-62; dopolnila in slogovno-ikonografska analiza: Golob 2013, 39-57.

23 Temeljni seznam Monaldovih rokopisov je objavil Brancale, 1982, 65-80; seznam z več dopolnitvami šteje kakih 30 popolnih in fragmentarnih rokopisov, ne more pa biti popoln, ker je veliko pravnih enciklopedij fragmentiranih in je identifikacija - na daljavo - nemogoča. 
V tem rokopisu je približno 900 pravnih členov, ki jih spremlja malo več kot 1600 obstranskih risbic, več jih je $\mathrm{v}$ prvi polovici kodeksa. Te imajo dva značaja: bodisi so pojmovno tako nazorne, pripovedne, da je mogoče takoj prepoznati vsebinski sklop, na katerega se nanašajo, bodisi kot kazalke opozarjajo na pomemben odlomek v strokovnem geslu; oboje so razsute po prostem robu, levo in desno od pisnih stolpcev. Rubrike uvajajo $\mathrm{v}$ pravne termine, a pisava $\mathrm{v}$ drobni univerzitetni gotici terja osredotočeno branje, za kar je potreben čas, medtem ko sličica "privede oko" do prave vsebine v bistveno krajšem času. Vse so samostojne (t. i. avtonomne risbe) in kompozicijsko zaokrožene - to je daleč od tega, kar je starejša strokovna literatura označevala kot »drolerije, figuralne igrače« in jih imela za naslikane nesmisle. Res so nekatere risbe morale zabavati bralca, ko se je prebijal skozi pravne formulacije. Skozi špranje pa gledajo tudi osebe različnih stanov: vojaki, kralji, menihi, obrtniki in ženske (posebno imenitni detajli so na fol. 16v, 223v, 91v, 146v, 148r, 159v itd.); njihovo družbeno vlogo prepoznamo po pokrivalih, oblačilih in predmetih. Povečini so narisani kot doprsja, vendar je takoj mogoče razbrati njihovo povezavo s pravnim določilom. $V$ tem procesu iskanja in prepoznavanja vsebin sodelujejo pravno besedilo, osebni spomin in likovno opozorilo, ki je pravzaprav v risbo spremenjena ključna beseda.

Sodelovala sta dva risarja. Prvi je ustvarjal v slogu pariške gotike, ki je vrh dosegla $\mathrm{v}$ času kralja Ludvika IX. Svetega. Kljub majhnim dimenzijam njegove risbe odlikuje občutek za realizem. Približno sto marginalnih risb je neposredno povezanih z vsebino, ob kateri so postavljene, zato je realizem v risarski potezi upravičen. Ob obsežneǰ̌ih geslih (o vojni, poroki, pokori) jih je več, ker je osnovno pravno določilo pospremljeno s primeri, ki slikarsko členijo pravne sklope. Te risbe imajo vlogo ključnih besed, ki neposredno opozarjajo na pravno sekvenco, tako da je pri njih risarski realizem nujen. Pri povezavi besedne razlage in likovne predstavitve pravnega termina ne sme biti spodrsljivega, nejasnega polja, ki bi z nedoločnostjo narisanega gesla bralca zavajalo. ${ }^{24}$ Ikonografija pravnega sklopa je zahtevala zgoščeno ponazoritev, vsaka $\mathrm{z}$ vsebino povezana risba je »povzetek«, »abstrakt« pravnega dejanja.

24 Nekaj nazornih primerov: fol. 18v: glava krščenca ob geslu Baptismo; 20r: Kristusova glava ob geslu Bigamia; 20v-21r: meč ter kraljeva in vojakova glava ob geslu De bello; 30r-30v: glava umorjenega ob geslu o ponovni posvetitvi cerkve po umoru; 37r: roka s ključem ob naštevanju nalog vodilnih klerikov; 46v: glava osebe, ki kaže jezik (poslanec ne sme biti mutast); 47v: obličje mrtveca (de mortem eius): kaj storiti, če odposlanec umre; 49v: na pol razvit meč (zadeve, ko je treba meč odložiti); 68r: kelih: svetih predmetov se ne sme prodajati; 73r: škofovska mitra ob poglavju o suspenzu škofa; 90v: obešen mošnjiček kot opozorilo tistim, ki porabijo denar, ki jim ne pripada; 177r: odsekana glava: kdor uporablja ponarejen denar, bo to plačal z glavo (de falsariis); 215v: vrč in kupa ob geslu o gostoljubju; 223v: glava arbitra ob geslu prorogatio; in še kakih 85 slikovno razloženih gesel. 


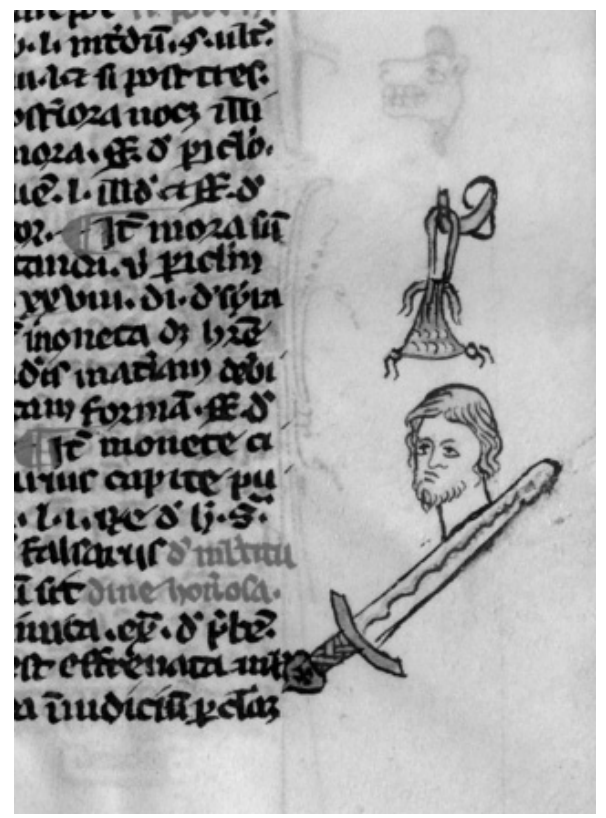

Slika 2: Kaznovanje prevaranta zaradi pohlepa ali ponarejenega denarja, Monaldus de Iustinopolis: Summa de iure canonico, ok. 1300, pariško delo (fol. 177r), Ljubljana,

Narodna in univerzitetna knjižnica, Ms 33. (c) Ljubljana, Narodna in univerzitetna knjižnica.

Pisanje o nesmiselnosti upodobitev (Kos-Stelè, 1931, 68) nas ne sme čuditi, ker je 20. stoletje pozabilo, da so pojmovni svet in čustveno zaznavanje v srednjem veku določali drugačni dispozitivi kot mnogo stoletij pozneje. Nekoliko je k napačnemu ocenjevanju pripomoglo tudi epohalno delo Émila Mâla o nabožni umetnosti 13. stoletja v Franciji, v katerem je avtor velikemu delu upodobitev pripisal vlogo dekoracije, posebej tistim, ki niso že na prvi pogled izkazovale nabožne ikonografije: takrat se je zdelo, da ni logike v neposrednem stiku med resnimi nabožnimi vsebinami in detajli, ki so v velike programe priromali iz na videz na glavo postavljenega sveta. Poznejši spisi o antropologiji in psihologiji srednjega veka so pokazali, da ima neposredni pogled prav tako svojo zrcalno podobo, da resničnost vsakdanjika razbremenjujejo humorni akcenti, da so številni zmaji pravzaprav povečani martinčki, da je v vsem veliko šaljivosti, pripovedk, basni, satiričnega in anekdotičnega itd. To je spomin, ki je imel (predvsem) govorjeno podobo in smo ga pozabili. Vendar je Mâlova knjiga vplivala na velik del umetnostne zgodovine 20. stoletja: zato so nekatere risbe na marginah Monaldove pravne enciklopedije pri bralcih rokopisov v 19. in 20. stoletju sprožile nasmeh, posmeh, nejevero in nerazumevanje. ${ }^{25}$

25 Primerjalna dela in razlago razpoloženja je orisal M. Camille v svoji knjigi o podobah na marginah: Image on the Edge. The Margins of Medieval Art; primerjalno zanimiva, ne pa interpretativno 
$\mathrm{Pa}$ je toliko stičnih točk med Monaldovim časom in nami: ko beremo dolga besedila, si - vsaj nekateri - ob strani napišemo besedico lire! (preberi!), NB (nota bene), klicaj ali vprašaj, valovito črto itd., vse, kar označuje misli, ki jih ne smemo spustiti iz spominskega trezorja. V srednjem veku so nanje opozarjali s svojimi znaki, z ročico, ki s stegnjenim prstom kaže na ključno besedo (manicula). To je bil standardni znak. Takšna kazalka se pojavi na prvih straneh Monaldove Summe, potem pa je bil spomin (in z njim pozabljivost, ta nesrečna in ne vedno zabavna protiutež) deležen smeha, ki je pridrl na plan v najbolj prismojenih kombinacijah. Prav pogosto je videti živalski gobec, skozi katerega se je stegnila roka (ali noga), ki kaže na pomemben odlomek, dva črva, ki z velikanskimi očmi gledata proti znanstveni vsebini, ljubeznivo prepletena laboda, ki sta prevzela vlogo oklepaja za nekaj vrst dolg odlomek (Slika 3), profil moškega, ki z jezikom, dolgim kot puščica, kaže na ključno besedo, cvetoča in olistana veja, ki se je prerinila iz gobca, kot da gre za poudarek, glej, misel, ki je šla v cvet. Vse to so risbe drugega risarja, karikaturista $\mathrm{v}$ službi naročnika rokopisa oz. bralca svobodnega duhà.

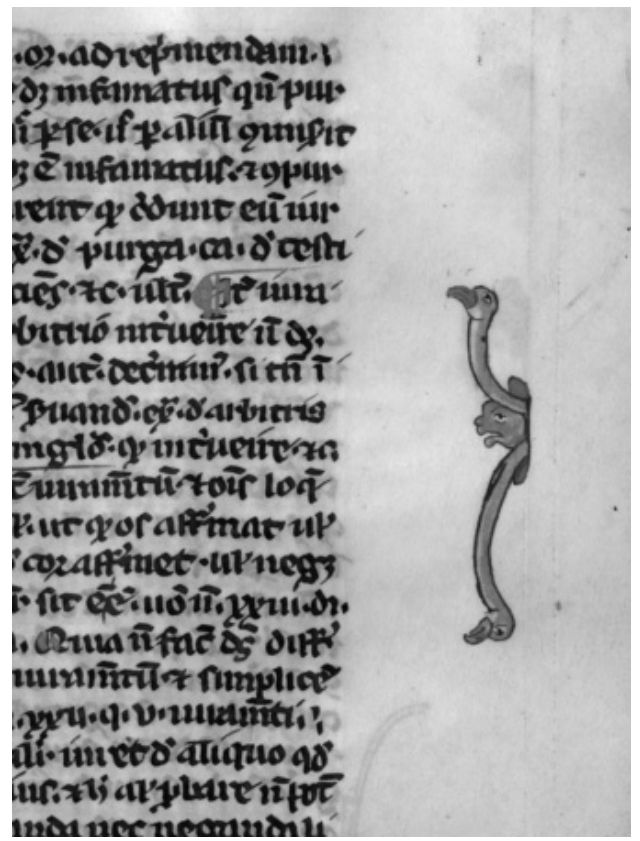

Slika 3: Zeleni labodji glavi, ki kot oklepaja označujeta vsebinsko pomemben odlomek, Monaldus de Iustinopolis: Summa de iure canonico, ok. 1300, pariško delo (fol. 133r), Ljubljana, Narodna in univerzitetna knjižnica, Ms 33. () Ljubljana, Narodna in univerzitetna knjižnica.

relevantna so naslednja podpoglavja: Annotation and the origins of marginal art ter Model and antimodel, str. 20-31 in Pricks, prayers and puns, str. 36-47. 
Te risbe velikokrat povezujejo odlomka, napisana več vrst vsaksebi, predvsem pa nadomeščajo ustaljene marginalne oznake. Razpoloženje $\mathrm{v}$ risbah je povsem drugačno od štimunge, ki jo vsebuje besedilo: na eni strani je resnobnost kanonskega prava, lepo urejenega $\mathrm{v}$ dva gosto pisana stolpca, kjer napake niso dovoljene, na drugi strani pa eruptivna likovnost. Pa je še kako pomembna, ker vsaka sličica podpira znanje, citat, definicijo. Bistvo tako urejenih strani je povezava med dvema načinoma komuniciranja, gre za sinergijo verbalnega in vizualnega zajetja izbrane strokovne vsebine.

Le nekaj desetletij poprej se je v nekaj rokopisih in listinah pojavila marginalna risba, ki je opozarjala na vsebinsko bistvo, npr. risba vinograda v urbarju ali seznamu desetine ${ }^{26}$ risba insignij ob odlomku o vladarjevih pristojnostih ipd. ${ }^{27}$ Gre za žanrske ilustracije (trezne, brez humorja), ki so oko privedle do iskanega mesta oz. vsebine. Zdi se, da je bil naročnik spominskih opor, naslikanih ključnih besed, v Monaldovem pravnem delu oseba $\mathrm{z}$ izjemnim znanjem in dragocenim smislom za humor, ki je marginalne risbe naročil zato, ker je vedel, kako naglo se oko izgubi v brezkončni pokrajini enako popisanih folijev. Vedel je tudi, da je proces učenja in zapomnjenja vsebin dolgotrajen, a kdor ga poseduje, se lahko kljub temu znajde v situaciji, ko je treba ob vsem znanju naglo preveriti definicijo ali imeti pri roki citat, ker je znanstveno delo proces, ki zahteva razmišljanje, predvsem pa preverjanje, reflektiranje postavljenega modela, ${ }^{28}$ znanje pa je nasledek znanosti.

$\mathrm{V}$ večstoletni praksi srednjeveške bralne kulture in memoriranja obsežnejših del je konvergenca obeh načinov dostopanja do zaželenih citatov-znanj-spoznanj-nasvetovdoločil itd. ${ }^{29}$ ustvarila tudi nove poti. M. Carruthers je 12. stoletje označila kot čas prehoda od razmeroma majhnih in homogenih samostanskih skupnosti s svojim konceptom memoriranja v ero, ko so se nekateri redovi obračali k bolj izobraženi in raznoliki javnosti, zaznamovani z urbanim ritmom in razvejanimi načini življenja; ${ }^{30}$

26 Npr. rokopis z naslovom Le Terrier de l'Éveque iz ok. 1275: Lille, Archives dep. du Nord, Ms 3 G 1208; ali Rentier d'Audenarde, tudi ok. 1275, Bruxelles, Bibliothèque Royale, Ms 1175; detajli so objavljeni v Stones, sl. 4, 5, 6 .

27 Vatican, Codex Reg, Vat. 5, fol. 176r; ta detajl je objavljen na spletni strani: http://classes.maxwell.syr. edu/his311/innociiireg.jpg [24. 5. 2016].

$28 \mathrm{~V}$ tem primeru imam $\mathrm{v}$ mislih ubesedenje modela pravne znanosti.

29 Na misel pride določilo iz Regula Magistri (Cap. 44), naj med odsotnostjo iz samostana menihi, ki nimajo s seboj Biblije, kratka berila a animo recitet, non in codice legat. Navodilo v nadaljevanju pravi ... ut quando in quovis loco codex deest, textum lectionis vel paginae, si opus fuerit, memoria recitetur ... in iz tega izvemo, da so morali menihi vsaj nekatere odlomke znati na pamet. To pa pomeni, da so potrebovali čas, da so si brez napake zapomnili vsaj ustrezne, tehtne odlomke. Prim. Weissenberger (1973, 51-62), navedeni odlomek je na str. 54.

30 Carruthers, M. (2000) pravi v uvodu: »The monastic practice of meditation notably involved making mental images or cognitive 'pictures' for thinking and composing. The use of such pictures, I will argue, derives both from Jewish spirituality and from compositional practices of Roman 
profana, mestna javnost, ki je imela glede na družbene spremembe bolj praktične poglede na življenje, je pričakovala tudi praktično (!) zasnovane knjige (Carruthers, P., 2004, 33 in dalje). Monaldova Summa je vrhunski primer znanstvenega priročnika, ki iskani citat »polaga v oči «.

Literaturo in znanost je obvladovala prepletenost oralne, vizualne in verbalne komunikacije, ${ }^{31}$ verjetno pa še njenih drugih oblik, npr. gestualne in situacijske. Spremembe v dojemanju besedila, ki je dobilo dodatno oporo z vstavljenim likom, simbolom ali znamenjem, so se pretvorile v nove, raznovrstnejše oblike. Zaradi večjega števila ohranjenih kodeksov jih doživljamo kot pogostejše, kar ne more biti povsem $\mathrm{v}$ skladu z nekdanjo resničnostjo. ${ }^{32}$ Pravil, ki veljajo npr. za pomen obstranskih risb v literarnih delih, ${ }^{33}$ priročnikih, listinah ipd., namreč ni mogoče linearno prenesti na dela npr. nabožne ali znanstvene literature. Oblikovna in pomenska prisotnost risb je živa in neposredno zgovorna samo $\mathrm{v}$ pogledu bralca, njegov pogled pa je zaobjemal tudi druge miselne procese, spoznavanje ali poznavanje vsebine dela, ki ga je imel v rokah, vseboval pa je tudi bolj ali manj zavestno naslanjanje na izkušnje, ki so mu bile spominske opore. Proces memoriranja in uporabljanja besed, besednih zvez, aluzij, metafor itd. $v$ dobršni meri temelji na podobah, ki so se skozi leta (gre za proces šolajočega očesa) vanj vtisnile v bralnem oz. receptivnem procesu bralca (Carruthers, M., 2000).

Približno pol stoletja preden je nastal ljubljanski rokopis Summae Monaldinae, je Albert Veliki povezal spoznavanje in pomnjenje podob (De bono, ok. 1246), kar je M. Carruthers strnila takole: »Albertu Velikemu je bilo jasno, da so spominske opore pragmatično zamišljene kognitivne sheme in ne realni objekti. Ponazorjene so lahko bile s katerimkoli predmetom (cerkvijo, palačo, vrtom), vendar niso bile realne. $\aleph^{34}$

Misliti v podobah je bil način, ki so ga pri predavanjih s pridom uporabljali profesorji. Exemplum je služil za boljšo ponazoritev in konkretizacijo teoretično

rhetoric. The emphasis upon the need for human beings to 'see' their thoughts in their minds as organized schemata of images, or 'pictures' and then to use these for further thinking, is striking and continuous feature of medieval monastic rhetoric, with significant interest even for our own contemporary understanding of the role of images in thinking. And the monks' 'mixed' use of verbaland visual media, their often synaesthetic literature and architecture, is a quality of medieval aesthetic practice that was also given a major impetus by the tools of monastic memory work. « Nav. delo, 3 .

31 Mostaert, M., 1999, 15-37; pomembno je upoštevati njegovo stališče, da vse oblike komuniciranja niso bile dostopne vsem slojem, str. 21-23.

32 Izkrivljen pogled povzroča število ohranjenih oz. izgubljenih rokopisov; čim bolj se premikamo proti zgodnjemu srednjemu veku, manj je rokopisov.

33 Huot, S., 1992, 3-14; ob rokopisu Chansonnier N, zdaj: New York, Pierpont Morgan Library, Ms 819, govori o dveh ravneh vizualne interpretacije besedila, ki je literarna in alegorična.

34 Carruthers, M., 2000, gl. poglavje: Collective memory and 'memoria rerum', 7-59; citat na str. 13. 
zastavljene misli, prav tako so exempla - kakor je bilo že omenjeno - v svoje nastope vključevali tudi pridigarji, ki so morali pridobiti pozornost poslušalcev in doseči razumevanje (Kompatscher, 1998, 77-78). Stoletje, v katerem sta živela Monaldus in naročnik marginalnih risbic v rokopisu Summae, je bilo čas različnih priročnikov. Ob že omenjenem delu Summa de arte praedicandi Thomasa de Chobhama se spomnimo tudi na spise Alana z Otokov, Jacquesa de Vitryja itd. $\mathrm{V}$ teh priročnikih je začetna črka praviloma poudarjena - iniciale namreč strukturirajo besedilo -, in če je bila v njih podoba bistvenega sporočila nekega odlomka, so take pripovedne iniciale postale prostor za likovni povzetek - abstrakt - zraven napisanega besedila.

Risbe na marginah Monaldovega rokopisa imajo vlogo funkcionalnega opozorila in so en (!) del celotne vsebine (Mostaert, 1999, 35-36); vsekakor so sredstvo za prepoznavo besedila in kot take so z njim nedeljivo povezane. Naj se za zaključek dotaknem tistih besed, ki jih je v traktatu De Memoria Artificialis (ok. 1335) zapisal Thomas Bradwardine. Pravi, da morajo biti podobe objektov, ki si jih je treba zapomniti, stvaritev posameznika in morajo biti prav njemu v prid. To je izrazil $\mathrm{z}$ mislijo, da »ni mogoče dati nasveta, ki bi enako veljal za vse. A vsak bi se moral potruditi in zase (!) uporabiti ta nasvet: vsak ohranja spomin po svoje in zato je pametno, da svojemu načinu sledi brez spreminjanj. ${ }^{35}$ Iz tega lahko izpeljemo predvidevanje, da podobe kot mnemonično sredstvo na drugo osebo ne učinkujejo $\mathrm{z}$ enako prepričevalno in enako spominsko močjo kot na »avtorja podob«. Na širši krog bralcev imajo bolj ali manj enako izražen in pričakovan učinek le univerzalno oblikovana znamenja, v katerih ni individualnega koncepta.

Nekako na časovni sredini med mislimi Alberta Velikega in Thomasa Bradwardina je v Parizu nastal ljubljanski rokopis, ki se zdi vizualizacija njunih razglabljanj. Obe besedili sta psihološki analizi človekovega zapomnjenja in uporabe spominskih sider, hkrati pa sta zrcalo tedanjega razmišljanja o vizualnem spominu, ki ni moglo biti lastno samo njima, ampak je obstajalo v intelektualnih krogih. V stoletju 1250-1350 je socialna psihodinamika utirala poti za vse bolj učinkovito izrabo obstoječih možnosti (za pridobivanje znanja ali dostopanje do njega) posameznika ali skupine. Naj je naročnik rokopisa vedel ali ne, kakšen proces v razvijanju pragmatičnih podpor se je v letih njegovega življenja sprožil, je treba priznati, da je njegov koncept obravnavanja pravnih vsebin s pomočjo slikovnih ponazoril najznačilnejših in splošno znanih likov (ob vedno enako oblikovanih stolpcih besedila) v resnici inventivna zamisel, ki je spremenila rabo dolgega in zapletenega znanstvenega besedila.

35 Angleški prevod tega odlomka je delo Mary Carruthers, 1990, 285. O tem vidiku piše tudi L. Freeman Sandler, 1997, 1-49, zlasti str. 40-41. 


\section{Bibliografija}

\section{Viri}

Aristotle, On the Soul. Parva naturalia. On breath, London, Cambridge (Ma) 1957.

Bartholomaeus Anglicus, De proprietatibus rerum [Basel: Berthold Ruppel, ok. 1470], München, Bayerische Staatsbibliothek, Ink B-92.

Gregorius Magnus, Registrum epistolarum, CCSL (Corpus christianorum Series Latina), Turnhout: Brepols, 1982.

Thomas de Chobham, Summa de arte praedicandi (ur. Morenzoni, F.), Turnhout 1989.

\section{Literatura}

Appleby, D., Instruction and Inspiration through Images in the Carolingian Period, v: Word, Image, Number. Communication in the Middle Ages (ur. Contreni, J. J., Casciani, S.), Tavarnuzze 2002, str. 85-111.

Brancale, G., Indice analitico dei codici continenti la Summa del B. Monaldo, v: Beato Monaldo da Giustinopoli. 1210-1280 ca. Atti raccolti in occasione del VII centenario del suo transito, Trieste 1982, str. 65-80.

Camille, M., Image on the Edge. The Margins of Medieval Art, London 1992.

Carruthers, M., The Book of Memory: A Study of Memory in Medieval Culture, Cambridge 1990.

Carruthers, M., The Craft of Thought. Meditation, rhetoric, and making of images 4001200, Cambridge 2000.

Carruthers, M., Intention, sensation et mémoire dans l'esthétique médiévale, Cahiers de civilisation médiévale 55, 2012, str. 367-378.

Carruthers, P., The Nature of the Mind. An Introduction. New York, London 2004.

Cobban, A., English university life in the Middle Ages, London 1999.

Coleman, J., Ancient and Medieval Memories. Studies in the Reconstruction of the Past, Cambridge 1995.

Das Kloster St. Gallen und seine Schulen. Zum 200. Geburtstag der Katholischen Kantonalsekundarschule »Flade«, St. Gallen 2009.

Duggan, L. G., Reflections on »was Art Really the ,Book for the Illiterate? «, v: Medieval Images and Texts as Forms of Communication. Papers from the Third Utrecht Symposium on Medieval Literacy (ur. Hageman, M., Mostert, M.), Turnhout 2005, str. 109-119. 
Freeman Sandler, L., The Study of marginal imagery: Past, present, and future, Studies in Iconography, 18, 1997, str. 1-49.

Freeman, A., Scripture and images in the Libri Carolini, Settimane di studio del Centro Italiano di Studi sull'Alto Medioevo 41, 1993 (1994)/1, str. 63-188.

Golob, N., Monaldova pravna enciklopedija kot rokopisna umetnina: Monaldus de Iustinopolis: Summa de iure canonico (Ms 33, Narodna in univerzitetna knjižnica v Ljubljani), v: Beatus Monaldus Iustinopolitanus: Summa de iure canonico (ur. Štoka, P., Markovič, I.), Koper 2013, str. 39-57.

Huot, S., Visualization and Memory, The Illustration of Troubadour Lyric in a Thirteenth-Century Manuscript, Gesta, XXXI/1, 1992, 3-14.

Klarer, M., Ekphrasis, or the archeology of historical theories of representation: medieval brain anatomy in Wernher der Gartenaere's Helmbrecht, Word \& Image, 15/1, January-March 1999, str. 34-40.

Kompatscher, G., Erbauungs- und Unterhaltungsliteratur des Mittelalters: Beispiele aus dem Handschriftenbestand der Universitätsbibliothek Innsbruck, Kulturerbe und Bibliotheksmanagement. Festschrift für Walter Neuhauser zum 65. Geburtstag am 22. September 1998. Biblos-Schriften, Band 170, Innsbruck 1998, str. 75-88.

Manzari, F., Stabile, G., Aristotele latino: Analytica priora, Analytica posteriora, Topica, De sophisticis elenchis, v: Vedere i Classici. L'illustrazione libraria dei testi antichi dallétà romana al tardo medioevo (ur. Buonocore, M.), Rim 1996, str. 254-256.

Mostaert, M., New Approaches to Medieval Communication?, v: New Approaches to Medieval Communication (ur. Mostaert, M.); (Utrecht Studies in Medieval Literacy 1), Turnhout 1999, str. 15-37.

Peklar, B., Iracionalna podoba srednjeveške umetnosti: spanje - sanje - smrt, Ljubljana 2016 (neobj.).

Rischpler, S., Die Ordnung der Gedächtnisfiguren: der bebilderte MnemotechnikTraktat Cod. 5393 der Österreichischen Nationalbibliothek, Codices manuscripti 48/49, junij 2004, str. 73-87.

Sprigrath, G. K., Zum Vergleich von Schrift und Malerei in den Briefen Gregors d. Großen an Serenus, http://www.phil-hum-ren.uni-muenchen.de/php/Sprigath/ GregSer.pdf. [17. 7. 2018].

Stones, A., The 'Terrier de l'Evêque' and some Reflections of Daily Life in the Second Half of the Thirteenth Century, v: Tributes to Jonathan J. G. Alexander. The Making and Meaning of Illuminated Medieval \& Renaissance Manuscripts, Art \& Architecture (ur. L'Engle, S., Guest, G. B.), London, Turnhout 2006, str. 371-384. 
Tarn Steiner, D., Images in Mind. Statues in Archaic and Classical Greek Literature and Thought, Princeton, Oxford 2001.

Weissenberger, P., OSB, Die Regula Magistri und die Regula S. Benedicti in ihrem Verhältnis zur Schreib- und Lesekunst wie zum Buch, Gutenberg Jahrbuch, 1973, str. 51-62.

Žbontar, Z., Visions and dreams in Antiquity and in the Middle Ages, Ikon: časopis za ikonografske studije / Journal of the iconographic studies 6, 2013, str. 267-274.

Žbontar, Z., Vizualna kultura zgodnjega srednjega veka: stičišče kolektivnega spomina in mentalitet, Ljubljana 2016 (neobj.). 


\section{Nataša Golob}

\section{O spominu in spominski podobi v srednjem veku}

Ključne besede: naslikane ključne besede, kazalke, traktati o spominu, medicinska dela o možganih in spominu

Prispevek govori o odnosu srednjeveških avtorjev do spomina tako v teoretičnem smislu kot tudi v praktični rabi, predvsem šolski praksi, kjer je bilo urjenje spomina pomembna veščina. Na odnos do spomina, spominjanja in urejanja informacij so zelo vplivali antični avtorji (zlasti Aristotel), katerih spoznanja so od patrističnega časa dalje vključevali v teološke razprave (Gregor Veliki, Izidor iz Sevilje). Visoki srednji vek se je pod vplivom arabskih del posvetil tudi medicinskemu opredeljevanju funkcioniranja možganov in intelektualnih sposobnosti (Avicenna), to pa se je izrazilo $\mathrm{v}$ anatomskih traktatih ter je vplivalo na razvoj miselnih vzorcev in likovnih ponazoritev vsebinsko odvisnih kvalitet. Kot posebna oblika označevanja pomembnih odlomkov in vizualne opore bralcu, ki išče specifične odlomke v obsežnem znanstvenem delu, je kot primer $\mathrm{v}$ središče postavljena enciklopedija kanonskega prava. Gesla v tem obsežnem delu so ponazorjena $\mathrm{z}$ realističnimi sličicami, ki so tako rekoč likovni povzetki in tako naslikane ključne besede, na pomembne odlomke pa opozarjajo kazalke v obliki fantazijskih detajlov (Monaldo Koprski: Summa de iure canonico, Ljubljana, Narodna in univerzitetna knjižnica, Ms 33). Govorimo lahko o stvaritvi, ki izraža koncept individualno zasnovanega spominskega sistema s slikovnimi oporami. 


\section{Nataša Golob}

\section{On Memory and Memorative Image in the Middle Ages}

Keywords: painted key-words, pointing fingers, treatises on memory, medical works on brain and memory

The paper discusses the attitude of mediaeval authors toward memory within theoretical approaches and also in practical use, which were especially valuable in scholastic practice, with the training of memory an important discipline. The authors of antiquity heavily influenced the perception of memory, remembrance and organizing the information (especially Aristotle), and since Patristic era their concepts were incorporated in theological texts (Gregory the Great, Isidore of Sevilla). During the later Middle Ages under the influence of Arab texts more attention was dedicated to the medical aspects of functioning of brains and intellectual capabilities (Avicenna), as seen in anatomical treatises and influencing the development of mnemonic patterns and visual expressions of qualities that are interrelated. Being a specific result of mnemonic practice, where important segments of text are accentuated with visual symbols, thus helping the reader in finding the relevant part in a vast scientific work, the paper sets at the centre an encyclopaedia of canon law. Subject headings in this extensive encyclopaedia are enhanced with realistic images, being actually pictorial abstracts and therefore painted key-words, while the attention to important passages is drawn with pointing-signs in the forms of imaginative details (Monaldus Iustinopolitanus: Summa de iure canonico, Ljubljana, National and University Library, Ms 33). We are thus able to speak of creation, expressing the concept of individually composed mnemonic system, supported with pictorial aids. 